\title{
Epidemiological and identification study of mange mites infestation in sheep in Al-Diwaniyah province
}

\author{
M. A. A. Al-Shebani K.A. Dawood G.A. Jassem \\ Coll. of Vet. Med./Al-Qadissiya University
}

\begin{abstract}
This study was conducted to investigate the percentages of infestation of mange Mites in sheep in different regions of Al-Diwaniyah province and the effects of age, sex of animals on the prevalence of the disease were studied also.The results of the microscopical examination of the skin scraping were revealed that 186 of the sheep were infested with mites with an overall percentage of infestation 3.65\%.In this study four genera of Mange Mites were recorded that parasitized sheep: Sarcoptes scabiei, Psoroptes ovis , Chorioptes spp. , Chirodiscoides caviae (fur mite) with rates 31.18\%, 52.15\%, 8.06\%, 2.15\% respectively where the genera of Chorioptes spp. and Chirodiscoides caviae recorded for the first time in Iraq, in addition to the presence a mixed infestation such as Sarcoptes with Psoroptes $5.91 \%$ and Psoroptes with Chorioptes $0.53 \%$.The prevalence of the infestation was highest in sheep more than two years old $(3.74 \%)$ and the lowest in sheep with age less than two years old (3.40\%). The prevalence of Mange Mites in male sheep was $3.93 \%$ versus $3.59 \%$ in females. Statistically there were no significant differences $(\mathrm{P}>0.05)$ according to the age and sex of animals, but the differences in percentages of infestation were significant $(\mathrm{p}<0.05)$ according to different regions of study.
\end{abstract}

\section{Introduction}

Humans have known Mites for along time. The Greeks referred to Acari which meant mites but they remained unknown until the beginning of the 17 th century. The researches and studies since that time indicated the presence of various species of this organism parasitizing on vertebrate and invertebrate animals as ectoparasites or endoparasites(1). Ectoparasites are ubiquitous, often highly damaging and in most cases cannot be permanently eradicated; hence, they must usually be managed locally with insecticides, some ectoparasites also act as vectors of protozoa, bacteria, viruses, cestodes and nematodes. The behaviour of ectoparasites also may cause harm indirectly, causing disturbance, increasing levels of behaviour such as rubbing, and leading to reduced time spent grazing or ruminating and in some cases to self wounding (2). Mange is a contagious skin disease characterised by crusty, pruritic dermatitis and hair/feather loss, and caused by a variety of Mange mites which are mostly weakly sclerotised,

\section{Materials and methods}

Field study: The study was carried out in different regions of AL-Diwaniyah slow-moving, very small (100-900 $\mu \mathrm{m})$, and live permanently on their hosts burrowing in or living on the skin. The French term for mange is 'la gale', and in English, it has been called 'itch', 'scab', or 'scabies'. Numerous species of mites cause mange specifically on domestic hosts (livestock, poultry). About 50 mite species in 16 families and 26 genera may cause mange where all the major mange mite species are within the orders Astigmata and Prostigmata. The Astigmata include the medical or veterinary important families Sarcoptidae and Psoroptidae which include Sarcoptes mite that causes sarcoptic mange (scabies) in humans and other mammals as a zoonotic disease(3).The main objectives of this study were to isolate and diagnose species of mites that cause mange in sheep and determine the prevalence of the disease in the different regions of AL-Diwaniyah Province and study the effect of the age and sex on the prevalence of disease .

province including (AL-Diwaniyah center, AL-Daghara, Sumer, AL-Saniyah, AL- 
Hamza, Nuffer, AL- Diwaniyah Slaughter House). A total number of examined sheep were 5093 in different ages, sexes which examined clinically. 266 samples(skin scraping) were collected from the sheep suspected with mange mites infestation. The clinical signs such as severe itching, wool loss, crusts and pustules were noticed.Depending on (4) the animals were divided into two groups of age : 1st group less than two years old ( 1380 sheep ) and 2nd group more than two years old (3713 sheep) and it also included (864 rams) and (4229 Ewes ), where 266 samples collected from the sheep suspected with mange mites infestation.

\section{Collecting of Samples}

Samples were collected from the animals which showed clinical signs of the mange infestation such as hair loss, severe itch and crusty or scaly skin lesions. The wool was clipped out with scissors and then a drops of glycerine were added on the edge of lesion to moisten the area then a skin scraping was taken from edge of lesion by using Scalpel and blade no.21

\section{Results}

The important clinical signs of the sheep infested with mite : itch where the animal attempts to rub the infested region of it's body with the legs, walls, fences, columns or biting with teeth, loss of wool. The wool becomes curly and like matted with the presence of calcified serous exudation leading to pigmentation with yellow color and easy to detach or remove and infested region seems wetness as a result of biting the animal to infested region repeatedly. Results of the laboratory tests revealed that 186 samples from a total of 266 samples collected from sheep were positive to mange mites while 80 samples were negative. The overall percentage of infestation with mange mites $3.65 \%$ from 5093 sheep examined.This study showed deeply until the blood begins to ooze, scraping is placed in a numbered Petri dish and the information is recorded for each animal on it, then transported directly to the laboratory for proceeding diagnosis (5).

\section{The laboratory Tests}

Depending on method of $(6,7)$ in microscopic examination for diagnosis, a part of the scraping was taken and placed in a test tube and 5 or $10 \mathrm{ml}$ of $\mathrm{KOH} 10 \%$ is added to it. The tubes are placed in a water bath with $80^{\circ} \mathrm{c}$ for 15 minutes then transported to a centrifuge in a speed of 1500-2000 rounds per minute for 5 minutes then the supernant is discarded by an automatic pipette and the sediment is mixed well in a test tube. Then some drops are drawn from the sediment with a pipette and placed on a glass slide and covered with a cover slide. It is examined under microscope with power $\mathrm{x} 10, \mathrm{x} 40, \mathrm{x} 100$ to confirm the presence of parasite and diagnose the species.Depend on formalism features of mites as described by $(7,8)$ in diagnosis of the samples of the study .

that the sheep were infested with four genera of Mange Mites included: Sarcoptes scabiei was 58 cases from a total of 186 case infested with Mange Mites with percentage $31.18 \%$ figure(2), Psoroptes ovis was 97 cases with percentage $52.15 \%$ figure(3), Chorioptes spp. was 15 cases with percentage $8.06 \%$ figure(4) and Chirodiscoides caviae (Fur Mite) was 4 cases with percentage $2.15 \%$ figure(5). mixed infestation were found in sheep Sarcoptes with Psoroptes 11 cases with percentage $5.91 \%$ while Psoroptes with Chorioptes was 1 case with percentage $0.53 \%$. A larvated egg of Sarcoptes scabiei and Psoroptes ovis also noticed figure (6). 


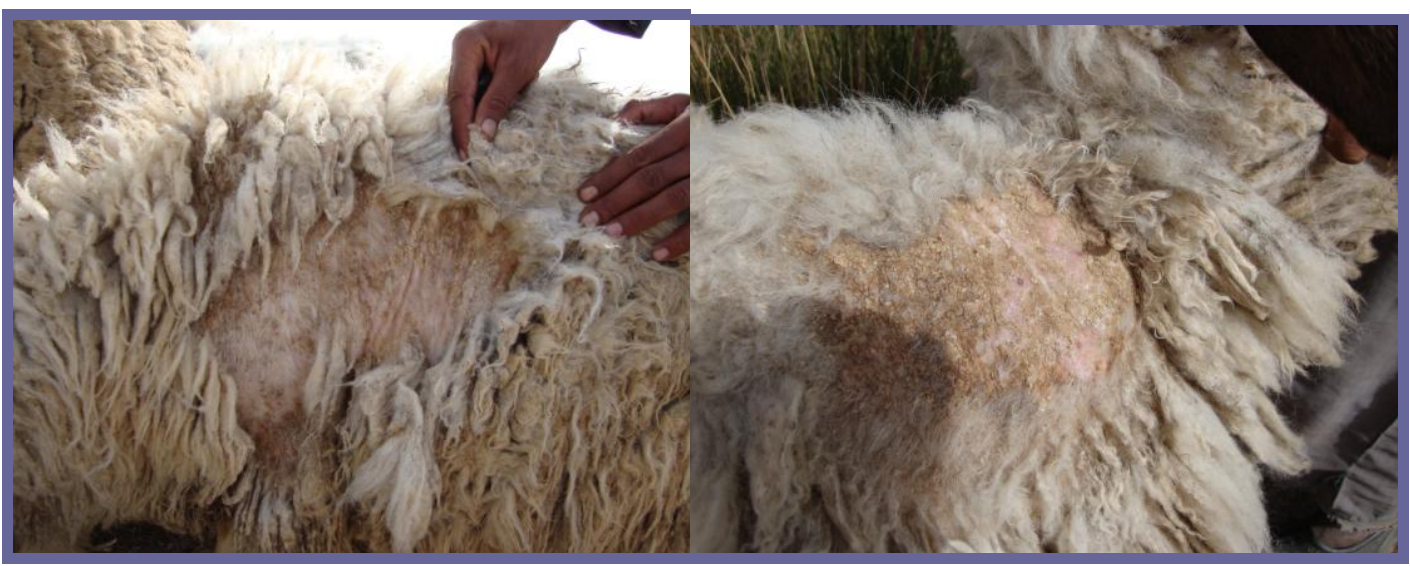

Figure (1) sheep infested with mange mite.

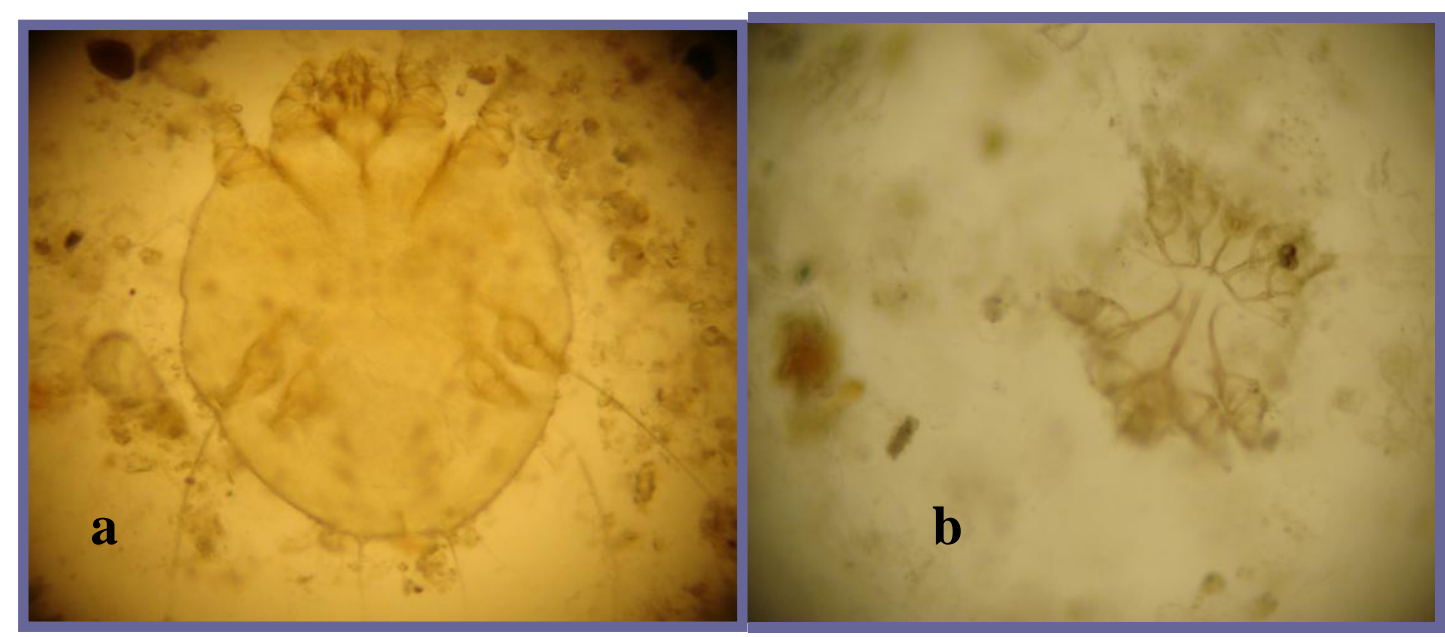

Fig. (2) ventral view of a. female of Sarcoptes scabiei b. male Sarcoptes scabiei x10.

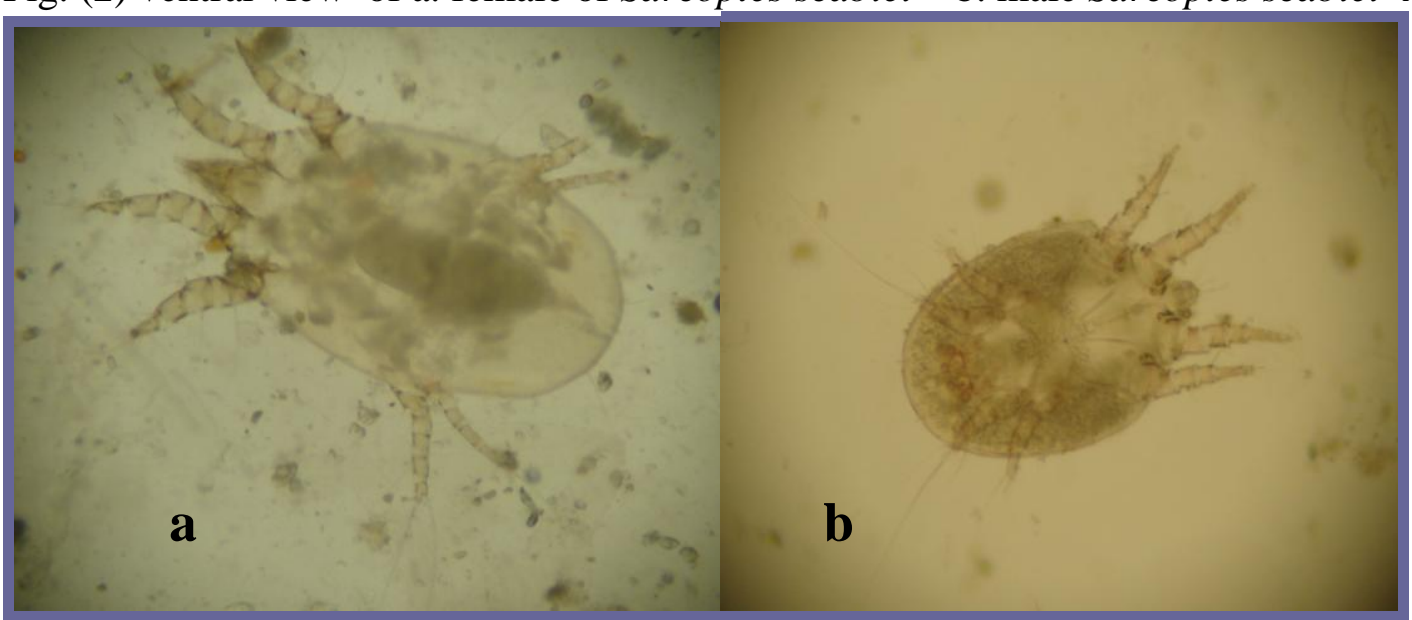

Fig. (3) a. ovigorous female of Psoroptes ovis . b. male Psoroptes ovis x10 . 
$\begin{array}{llll}\text { AL-Qadisiya Journal of Vet.Med.Sci. } \quad \text { Vol./11 } & \text { No./1 }\end{array}$

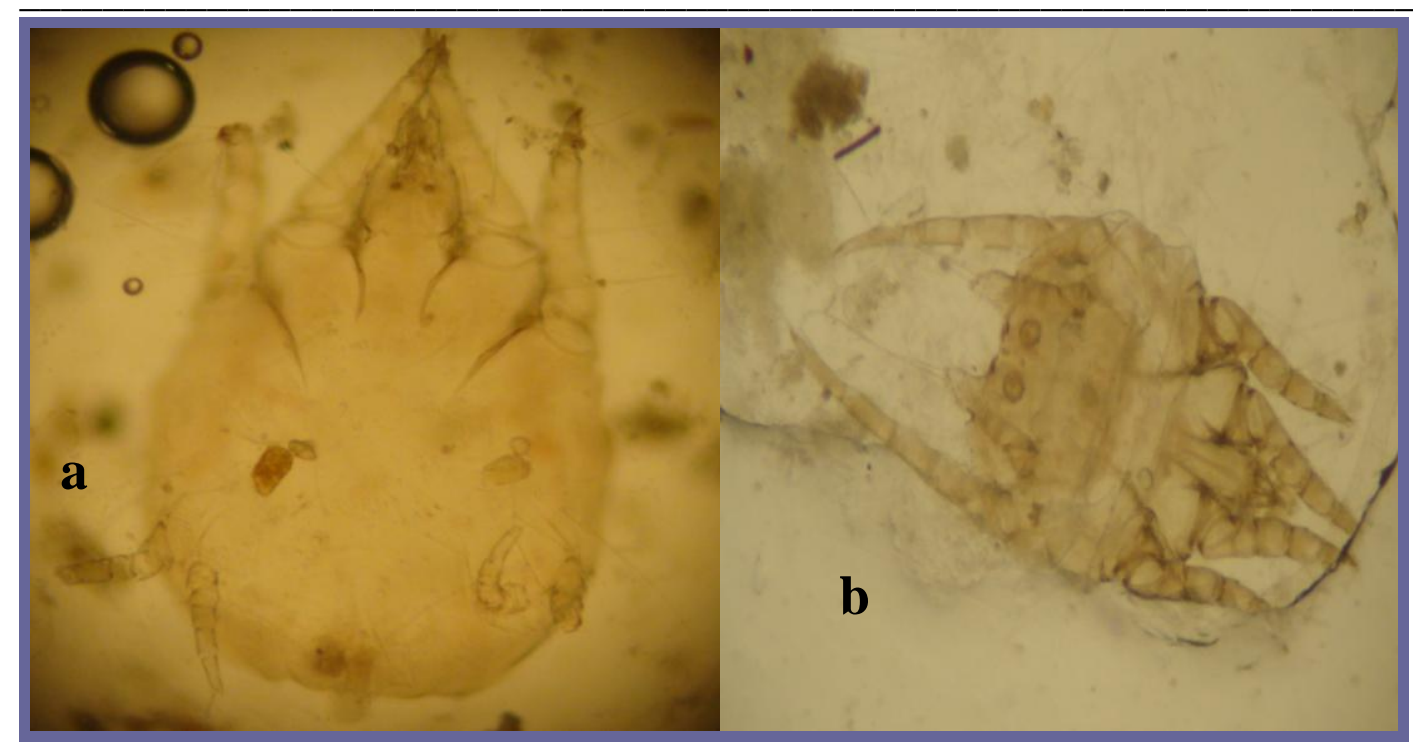

Fig. (4) Ventral view of female (a) and male (b) of Chorioptes spp. x10.

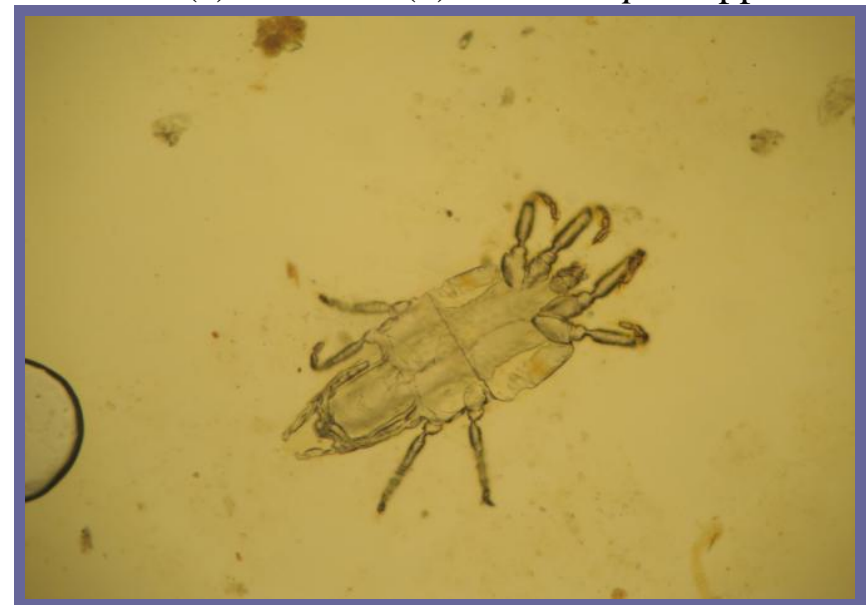

Fig. (5) a ventral view of Chirodiscoides caviae (fur mite) x10

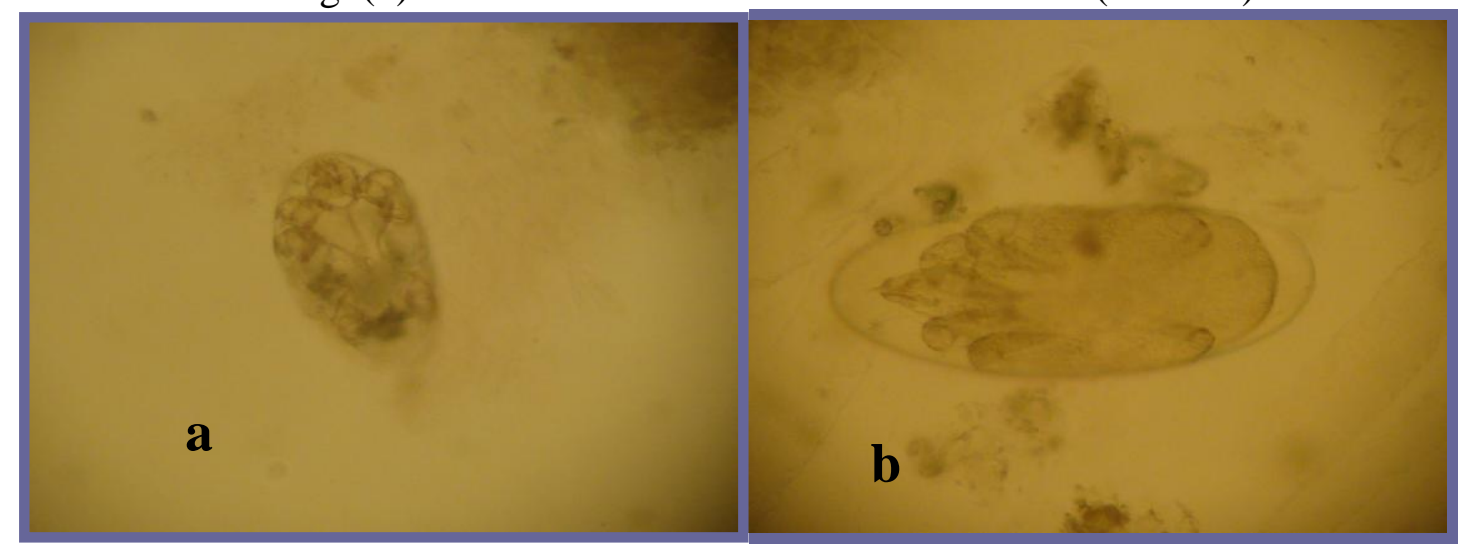

Fig. (6) a larvated egg of (a) Sarcoptes scabiei (b) Psoroptes ovis x10.

\section{Effect of Age and Sex on Infestation with Mange Mites}

Results of this study revealed that the percentages of the infestation were high in sheep more than two years old $3.74 \%$ and low in age less than two years old $3.40 \%$. On the other hand the high rates of mange mite infestation in male sheep (Rams) were $3.93 \%$ compared with the females(Ewes) $3.59 \%$, table (1). Statistically there were no significant differences $(\mathrm{P}>0.05)$ according to the age and sex of animals. 
Table (1) Relation of age and sex of animals with percentages of mite infestation in sheep :

\begin{tabular}{|c|c|c|c|c|}
\hline \multicolumn{2}{|c|}{ Age of animal } & $\begin{array}{l}\text { Number of examined } \\
\text { sheep }\end{array}$ & $\begin{array}{ll}\text { Number } & \text { of } \\
\text { infested sheep }\end{array}$ & $\begin{array}{l}\% \text { in comparison with } \\
\text { examined No. }\end{array}$ \\
\hline \multicolumn{2}{|c|}{ Less than 2 years } & 1380 & 47 & 3.40 \\
\hline \multicolumn{2}{|c|}{ More than 2 years } & 3713 & 139 & 3.74 \\
\hline \multirow[b]{2}{*}{ The sex } & Male & 864 & 34 & 3.93 \\
\hline & Female & 4229 & 152 & 3.59 \\
\hline
\end{tabular}

There were no significant differences on $(\mathrm{p}>0.05)$.

\section{Geographic distribution of Mange Mites infestation}

Results of the present study revealed that the highest infestation rates with mange mites in Al- Daghara region 9.18\% followed by Al-Diwaniyah center, Sumer, Al-Hamza, Nuffer, Al-Saniyah with rates $3.53 \%, \quad 2.59 \%, 2.06 \%, 2.02 \%, 1.85 \%$ respectively and the lowest infestation rates were in Al-Diwaniyah slaughter house $1.6 \%$, table (2). Statistically the differences in percentages of infestation were significant $(\mathrm{p}<0.05)$ according to different regions of study.

Table (2) Demonstrates the infestation percentages of mange mites in the regions of the study

\begin{tabular}{|c|c|c|cc|}
\hline Region of Study & $\begin{array}{c}\text { Number of } \\
\text { examined sheep }\end{array}$ & $\begin{array}{c}\text { Number of } \\
\text { infested sheep }\end{array}$ & \multicolumn{2}{|c|}{ \% in comparison with } \\
examined & No. \\
\hline Al-Daghara & 947 & 87 & 9.18 & $\mathrm{a}$ \\
\hline Sumer & 808 & 21 & 2.59 & $\mathrm{bc}$ \\
\hline Nuffer & 691 & 14 & 2.02 & $\mathrm{bc}$ \\
\hline Al-Diwaniyah center & 904 & 32 & 3.53 & $\mathrm{~b}$ \\
\hline Al-Saniyah & 648 & 12 & 1.85 & $\mathrm{c}$ \\
\hline $\begin{array}{c}\text { Al-Diwaniyah } \\
\text { slaughter house }\end{array}$ & 562 & 9 & 1.6 & $\mathrm{c}$ \\
\hline Al-Hamza & 533 & 11 & \multicolumn{2}{|c|}{$3.06 \mathrm{bc}$} \\
\hline Total & 5093 & 186 & \multicolumn{2}{|c|}{} \\
\hline
\end{tabular}

* The same letters indicates that the differences were not significant $(\mathrm{p}<0.05)$.

\section{Discussion}

The important clinical signs of the sheep infested with mite : itch and loss of wool and this agree with each of (9) clarified that causes of intense irritation and itching by toxins secreted from parasite lead to sensitization of animals and (10) referred that this parasite especially Sarcoptes mite burrows in the deeper parts of the stratum corneum, or the superficial layers of the stratum malpighii of the skin, and rarely goes deeper, it's compeletes its entire life cycle at this level, therefore; causes severe itching and loss of hair or wool.The overall percentage of infestation with mange mites in sheep was $3.65 \%$. Our finding nearished from the percentages readed by (1) in Iraq the whole percentage $3.74 \%$ and in Al-Diwaniyah province was $0.31 \%$ with Sarcoptes in sheep and (11) was $3.1 \%$ in sheep and (12) $1.2 \%$ in grazing sheep and $7.4 \%$ nongrazing with rate $4.3 \%$ with Chorioptes mite and (13) $2.6 \%$ with Sarcoptes mite in sheep in Urmia suburb, Iran .While this percentage was less than the percentages that get by each of (14) in Sudan were 50\% 
with Psoroptes communis var ovis in sheep and (15) in India was 8\% in sheep and (16) $18.3 \%$ with Psoroptes and sarcoptes in sheep and (17) $34.9 \%$ and (18) $21.0 \%$ in sheep with Sarcoptes scabiei in Highland Balochistan and (19) $28.1 \%$ with Psoroptes and sarcoptes in sheep and (20) was 52\% in sheep with Psoroptes \& Sarcoptes \& Chorioptes and $75 \%$ with Psoroptes and (21) $48.8 \%$ and most with Sarcoptes mite in small ruminants and (22) $22.96 \%$ with Sarcoptes and Psoroptes in sheep in Baghdad province and (23) in Spain with Sarcoptes in sheep were $12.6 \%$ and (24) 6\% with Sarcoptes mite and (25) $14 \%$ with Psoroptes mite and (26) was $15 \%$ of sheep scab in Scotland and(27) was $44.7 \%$ with Psoroptes in sheep.The causes for this variance may return to the variations of the environmental conditions and geographic areas(nature of earth and pastures) and mode of breeding and management of the animals and the variations of the numbers, breeds(nature of wool and it's length) and the species of the animals included in the study in addition to the increment of cultural awareness of owners in using modern ways for the prevention and control of the disease by using the broad spectrum Ivermectin for regularly period in year and dipping the animals using the effective

\section{References}

1.Hussein, M. A. (1979). Study of Mange Causes in Sheep and comparison the efficient of some insecticides. University of Baghdad (M.Sc. Thesis).

2.Wall, Richard .(2007). Ectoparasites: Future challenges in a changing world. Elsevier B.V., Veterinary Parasitology 148 : 62-74.

3.Wall, R. ; Smith, K. ; Berriatua, E. and French, N.P. (2001). Population growth and mortality of the mite Psoroptes ovis and novel approaches to control. Vet. Parasitol. 98 : 91-101.

4.Reece, W.O. (2005). Functional and Physiology of Domestic Animals. Lippincott Williams Wilkins. $\left(3^{\text {rd }} \mathrm{ed}\right)$. Pp: $314-316$. organophosphorous compound which leads to the destruction of all external parasites, the owners consider the mange as a serious and infectious disease, therefore; they tend to treatment or selling. Results of the present study recorded that the sheep were infested with four genera of the mange mites including: Sarcoptes scabiei , Psoroptes ovis, Chorioptes spp. and Fur mite Chirodiscoides caviae where the genera of Chorioptes spp. and Fur mite Chirodiscoides caviae recorded for the first time in Iraq . Our finding differs from those (1) and (16) and (19) and (22) and (27) who recorded that Iraqi sheep infested with Sarcoptes and Psoroptes Mites only and this is owing to the variance of the numbers and breeds of the examined animals and the nature of the geographic zones of study in addition to the time lag between their studies and the present study.Results of the present study revealed that the differences in numbers and percentages of infestation between age and sex of animals was non significant ( $p$ > 0.05 ) and this indicate that age and sex of animals not effect on infestation with mites. Our finding corresponds with each of $(23,25,28,29,30,31)$ who confirmed that age and sex of animals don't effect on percentage of infestation with mites.

5.Hendrix, C. M. and Robinson, E. (2006). Diagnostic Parasitology for Veterinary Technicians. $\left(3^{\text {rd }}\right.$ ed). Linda L. Duncan, Missouri, Newyork. P: 172-189.

6.Armitge, F.D. (1936). Amethod for preparation of many mites for microscopical examination Vet. Rec. 48: 1400-1406.

7.Baker, A. S. (1999). Mites and ticks of domestic animals, an identification guide and information source. Department of Entomology, The Natural History Museum. London, The Stationery Office.

8.Baker, A. S. (2010). Department of Entomology, The Natural History Museum , Cromwell Road, London SW7 5BD . Personal connection 
9.Kaufman, P. E.; Koehler, P. G. and Butler, J. F. (2009). External Parasites of Sheep and Goats . Institute of Food and Agricultural Sciences, University of Florida. ENY-273 (IG129). P: 1-14 . http://edis.ifas.ufl.edu.

10. Jones, T.s C. ; Hunt, R. D. and King, N. W. (1997). Veterinary Pathology . $\left(6^{\text {th }}\right.$ ed). Williams and Wilkins, Newyork. p: 677.

11. Bates, P.G. (1996a). Epidemiology of sub clinical Ovine psoroptic otoacariasis in Great Britian. Veterinary Record, 138: 388-393.

12. Yeruham, I. ; Rosen, S. and Hadani, A. (1999). Chorioptic mange(Acarina: Psoroptidae) in domestic and wild ruminants in Israel.Experimental and Applied Acarology 23 : 861-869.

13. Yakhchali, M. and Hosseine, A. .(2006). Prevalence and ectoparasites fauna of sheep and goats flocks in Urmia suburb, Iran. Veterinarski Arhiv 76 (5), 431-442.

14. Abu Samra, M.T.; Imbabi, S.E. and Mahgoub, E.S. (1981). Mange in domestic animals in the Sudan. Annals of Tropical Medicine and Parasitology, 75(6): 627-637.

15. Chakrabarti, A. and Chaudhury, M.N. (1984). Survey of the incidence of Mange in domestic animals in West Bengal (India). Ind. Vet. Med. J. 8 :39-48 (cited from Vet. Bull. 54(7263) 1984).

16. Abd, S. S. (1989). A Survey of Ectoparasites in Sheep and Goats. University of Baghdad (M.Sc. Thesis).

17. Johnson, P.W. ; Plant, J.W. ; Blunt, S.C. and Nicholls, P.J. (1990). The Prevalence of itch Mite, Psorergates ovis, among Sheep flocks with a history of fleece derangement. Aust. Vet. J. 67(4): 117-121.

18. Qudoos, A. ; Rafique, S.; Khan, Vl.; Iqbal, Z. and Riaz, M. (1997).Sarcoptic Mange in SttiEP in Highland Balochistan. Pak. J. Agri. Sci. Vol. 34 (1-4).

19. Al-badrani, B.A. (1998). Clinical and Therapeutic Study of Mange Disease of Sheep in Al-Mosul province. university of Al-Mosul (M.Sc. thesis).

20. Martinez, J. ; Reina, D.; Morato, E. ; Becerra, C. ; Navarrete, I. and Hernandez, S. (1999). Mange in Livestock animals in the south west of Spain. European cooperation in the field of scientific and technical research. Agric and Biotechnology. Workshops held at the Uni. Of Cluj, Romania.

21. Demissie, A.; Siraw, B.; Teferi, K.; Tsertse, T.; Mammo, G.; Mekonnen, D. and Shimelis, S. (2000). Mange: A Disease of Growing Threat for The production of small ruminants in the Amhara National Regional State. In: Merkel, R.C.; Abebe, G. and Goetsch, A.L. (eds.). The Opportunities and Challenges of Enhancing Goat Production in East Africa. Proceedings of a conference held at Debub, University Awassa, Ethiopia . pp: 80-91.

22. Al-Zubaidei, H. H. (2003). A Study of Prevalence of Ectoparasitic Infestation of Sheep in Baghdad. University of Baghdad (M.Sc. Thesis).

23. González-Candela, M. ; León-Vizcaíno, L. and Cubero-Pablo, M.J. (2004). Population Effects of Sarcoptic Mange in Barbary Sheep (Ammotragus Lervia) from SIERRA ESPUÑA Regional Park, Spain. Journal of Wildlife Diseases, 40(3). p: 456-465.

24. Aatish, H. U.; Sindhu, Z. U.; Iqbal, Z. ; Jabbar, A. and Tasawar, Z. (2007). Prevalence of Sheep Mange in District Dera Ghazi Khan (Pakistan) and Associated Hematological /Biochemical Disturbances . Int. Jour. Agri. Biol., Vol. 9, No. 6. p: 917-920. http://www.fspublishers.org

25. Tasawar, Z. ; Rauf, B. ; Hayat, C. S. and Lashari, M. H. (2007). Prevalence of Psoroptes ovis in Sheep around Multan, Pakistan. Pakistan Vet. J., 27(4) : 199-200.

26. Bates, P. ; Cook , A. ; Philips , K. ; Temple , M. ; Gettinby , G. and Kelly 
, L. .(2008). An evidence base for new legislation and guidance for implementation of a compulsory treatment period for sheep scab . p: $1-40$.

27. Al naaimi, O.A. and Al-badrani, B.A. ( 2010). Diagnosis of Psoroptic mange in Sheep by Modified Modified ELISA Test.Uni.of Mosul ,Iraq. Jour. Of Ani. and Vet. Advances 9(13): 1880-1884.

28. Heath, AC. ; Bishop, D.M. and Tenquist, J.D. (1983). The prevalence and pathogenicity of Chorioptes bovis (Hering, 1845) and Psoroptes cuniculi (Delafond, 1859) (Acari: Psoroptidae) infestations in feral goats in New Zealand. Vet. Parasitol. 13(2):159169.

29. Barth, D. and Visser, M. (1985). Comparison of two method for counting living mites in skin scraping. Zentralblatt Bakterioligie, Hygiene A, $260: 412$.

30. O'Brien, D.J. (1992). Studies on the epidemiology of psoroptic mange of sheep in Ireland. National University of Ireland. (Ph.D. thesis).

31. Bates, P.G. (1996b). The biology of Psoroptes ovis the Sheep Scab Mite. Proc. Conf. Sheep Scab Tralee, Ireland. P: 4-6.

\section{دراسة وبائية و تشخيصية لإصابات حلم الجرب في الأغنام في محافظة الأديو انية \\ غيداء عباس جاسم \\ خيرب عبد الله داود البهدئ \\ كلية الطب البيطري/جامعة القادسية \\ ميثم عسكر علوان الثباني \\ الخلاصة}

أجريت هذه الدراسة للتحرب عن نسب الاصدابة بحلم الجرب في الاغنام في بعض مناطق محافظة الديو انية، ودراسة الإنة

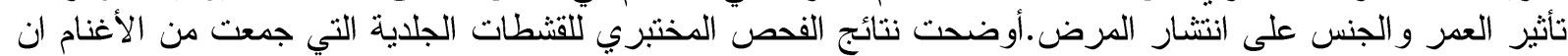

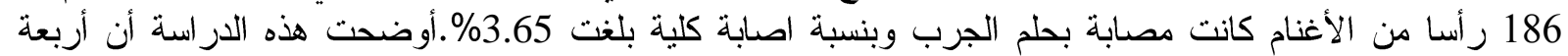

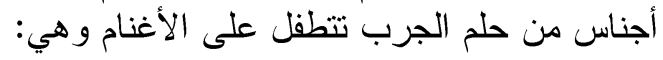

Chirodiscoides caviae ،Chorioptes spp. ،Psoroptes ovis ، Sarcoptes scabiei

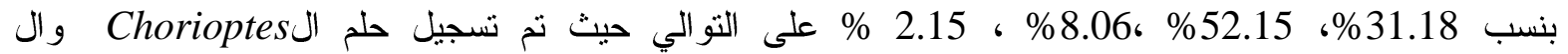

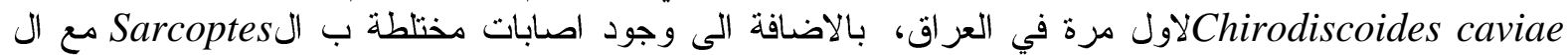

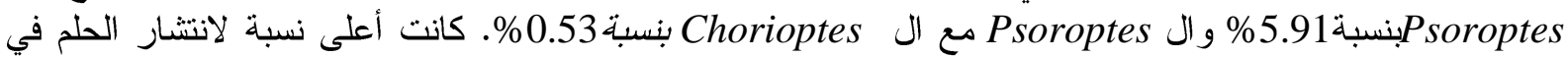

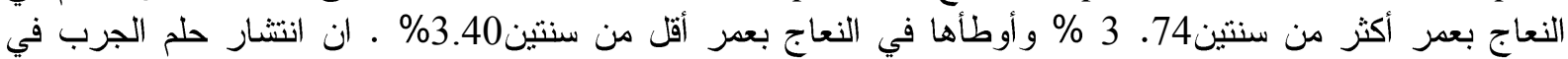

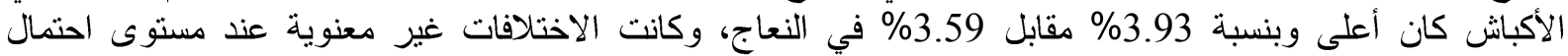
بالنسبة لعمر و جنس الحيو ان. بينما كانت معنوية (p>0.05) 